\title{
Folate Transporter 1
}

National Cancer Institute

\section{Source}

National Cancer Institute. Folate Transporter 1. NCI Thesaurus. Code C103948.

Folate transporter 1 ( $591 \mathrm{aa}, \sim 65 \mathrm{kDa}$ ) is encoded by the human SLC19A1 gene. This protein plays a role in the transmembrane transport of folate. 